\title{
Some Observations on Invasive Vascular Plant Species of the Eastern United States, New York to the Florida Keys
}

\author{
Research Article
}

Volume 1 Issue 1- 2020

\begin{abstract}
Author Details
Richard Stalter*

Department of Biological Sciences, St. John's University, USA

*Corresponding author

Richard Stalter, Department of Biological Sciences, St. John’s University, 8000 Utopia Parkway, Jamaica, NY 11439, USA
\end{abstract}

Article History

Received: December 18, 2020 Accepted: December 28, 2020 Published: December 29, 2020

\begin{abstract}
The objective of the present study was to compare the invasive vascular plant species at city, state, National Parks, and research preserves in New York, New Jersey, South Carolina and Florida, where the author has conducted research and published his findings in refereed journals. Sites with human activity have a high percent $(<50 \%)$ of invasive species. Invasive taxa have increased at "protected" sites where human impact is minimal posing a further threat to native vegetation. The deliberate introduction of exotic taxa such as Callery Pear, Kudzu, Multiflora Rose, Norway Maple, Oriental Bittersweet, and more pose a threat to native taxa.
\end{abstract}

Keywords: Invasive vascular plant species, New York, New Jersey, South Carolina, Florida, USA

\section{Introduction}

The objective of this short paper is the present data on invasive vascular plant species at several city, state, National Parks, and research preserves from New York to the Florida Keys. These sites harbor a wealth of plant communities including salt marsh, brackish marsh, mangrove, coastal dune, ruderal successional fields and woodlands, and mature woodlands. The sites presented in this paper were visited by the author over a number of years providing data for the present paper. The sites included in this study are Orient Beach State Park, New York [1], Liberty Island, NY [2]. Ellis Island, NY [3], Hoffman and Swinburne Island, NY [4], a five year study to sidewalk plots in Brooklyn and Queens NY [5], the High Line, an abandoned rail line in New York City [6], and an 83 year history of vegetation change at Alley Pond Park, a New York City Park, from 1935 to 2018 [7]. Human impact is high on all of the above sites except Hoffman and Swinburne islands at the mouth of the Hudson River bordering northeast Staten Island. All the aforementioned have a high percent of invasive taxa exceeding $60 \%$ with the exception of the flora of the High Line in 2002, $55.8 \%$ (Table 1).

Stalter et al. [8] conducted a floristic inventory of Rutgers University's ecological research woodland, Hutchison Memorial Forest comparing his data with that of Bard [9]. Bard [9] found 5 invasive taxa in the forest concluding that this mature forest was a closed community that could resist invasive taxa. Stalter examined herbarium specimens in
Rutgers Chrysler Herbarium and documented significant invasive introductions 19, since Bard's [9] floristic inventory. These new invasive taxa included Acer platanoides, (Norway Maple), Alliaria petiolata (Garlic Mustard), Celtis orbiculatus, (Oriental Bittersweet), Lonicera japonica, (Japanese Honeysuckle), Microstegium vimineum, (Japanese Stilt grass), and Rosa multiflora (Multiflora Rose). Of the above, Acer platanoides (Figure 1) and Microstegium vimineum are particularly injurious to native taxa. Microstegium is the dominant herbaceous plant at the Rutgers forest. It out competes native herbaceous vegetation. Its success is aided and abetted by a burgeoning white tail deer population that selective feeds on native taxa. Acer platanoides may prove to be a future problem as no plants were found under its dense shade. It is the first tree to leaf out in the spring and last to lose its leaves in the fall (Figure 1). The deep shade under its canopy has the potential of preventing oak regeneration at Hutchison Memorial Forest and forest sites in New York City parks where it has become established.

A study on abandoned rice fields in South Carolina by Stalter et al. [10] deals with vegetation change at the abandoned rice fields over 47 years with additional data dating back to 1915 . This study is significant as it provides data at these abandoned rice fields over 47 years by the same investigators. Rising sea level and a concomitant change in water salinity changed the structure of these plant communities; more saline tolerant taxa are replacing less saline tolerant taxa [10]. Moreover The recent introduction of invasive Phragmites australis (Tall Reed) in the 
three abandoned rice fields also contributes to the reduction of native vascular plant diversity, especially at the least saline field, Alderly (Figure 2).

Stalter has conducted ecological and floristic inventories in Florida; only 3 are included here: Garden Key [11], The Ding Darling National Wildlife Refuge, Sanibel Island [12] and the John J. Pescatello Torchwood Hammock Preserve, Little Torch Key (Table 2) (Stalter et al. 2020e in press). The Pescatello Preserves protected status enhances its stability enabling its stable flora to resist perturbations such as coastal storms and hurricanes. Access to the fenced Pescatello Preserve is limited; only $4 \%$ of the taxa here are invasive. Invasive taxa at Biscayne National Park are primarily at sites of high human activity; $21.6 \%$ of the taxa here are non-native. Most of the park experiences little human activity which accounts for its high percent of native vascular flora, $78.4 \%$.

Table 1: Frequencies of native versus non-native plants at High line 2002, High line 2019, New York, Hoffman and Swinburne Islands NY, (Stalter and Munir 2002), Liberty National Monument NY (Stalter and Tang 2002), Ellis Island, NY (Stalter and Scotto, 1999), Sidewalk Plots, Brooklyn and Queens, NY (Stalter and Rachlin 2018).

\begin{tabular}{|c|c|c|c|c|c|c|}
\hline & $\begin{array}{c}\text { High Line } \\
\mathbf{2 0 0 2}, \mathbf{N Y}\end{array}$ & $\begin{array}{c}\text { High Line 2019, } \\
\text { NY }\end{array}$ & $\begin{array}{c}\text { Hoffman \& Swinburne } \\
\text { Islands, NY }\end{array}$ & $\begin{array}{c}\text { Liberty Island } \\
\text { NY }\end{array}$ & $\begin{array}{c}\text { Ellis Island } \\
\text { NY }\end{array}$ & $\begin{array}{c}\text { Sidewalk Plots, } \\
\text { NY }\end{array}$ \\
\hline Native Species & 68 & 30 & 33 & 34 & 98 & 36 \\
\hline Non-native Species & 86 & 50 & 55 & 63 & 149 & 85 \\
\hline \% Non-native species & $55.80 \%$ & $62.50 \%$ & $63 \%$ & $65 \%$ & $60.30 \%$ & $68.90 \%$ \\
\hline Total Species & 154 & 80 & 88 & 97 & 247 & 121 \\
\hline
\end{tabular}

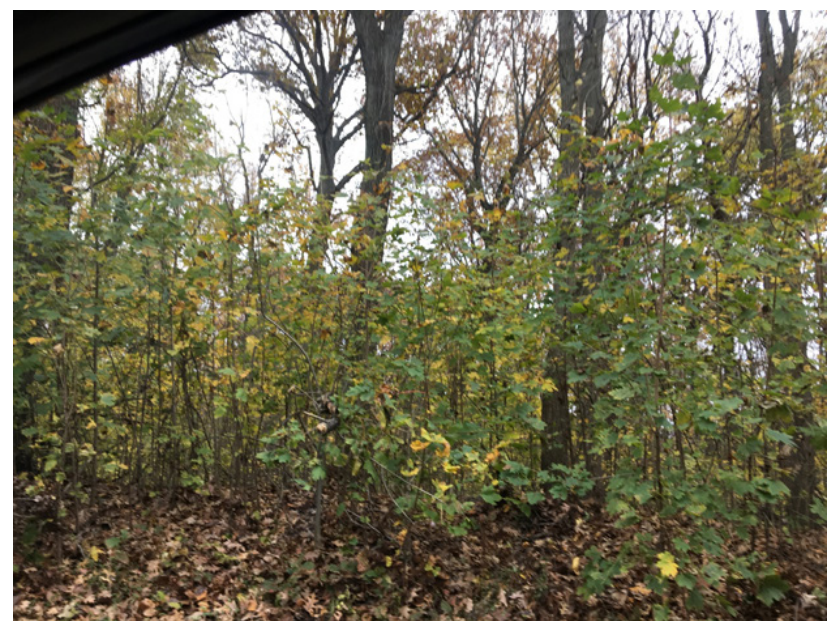

Figure 1: Acer platanoides, Cunningham Park, NY, 15 November, 2018. Norway Maple is the last to lose its leaves in the fall and first to leaf out in the spring. No vegetation was observed under its dense canopy at Hutchison Memorial Forest, New Jersey. Norway Maple may also pose a threat to tree regeneration in NYC parks in the future. Photo by J. Tong.

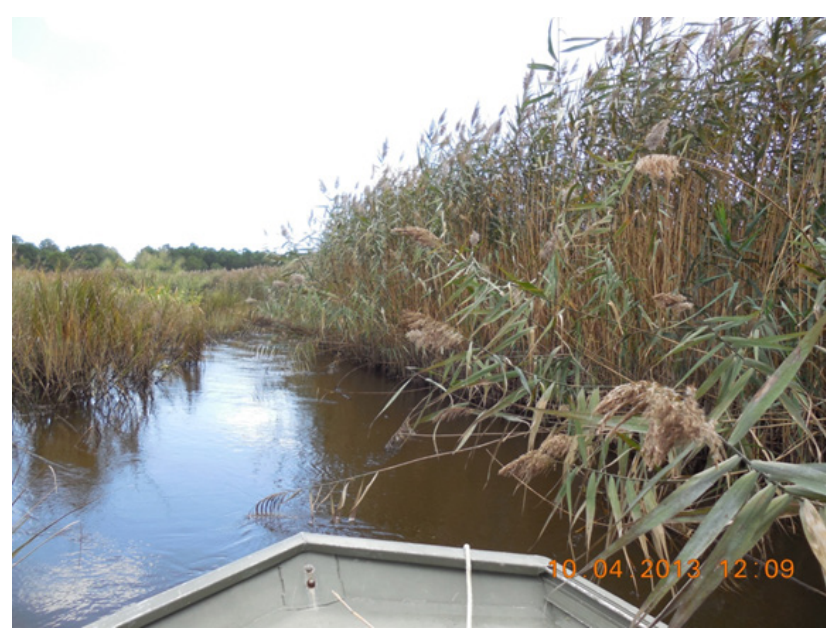

Figure 2: Phragmites australis, Alderly Marsh, Georgetown, SC. This invasive taxon forms pure stands in the abandoned rice fields. It was first observed in South Carolina by Stalter near the site where this photo was taken in 1975. Few if any vascular plant species can compete with Tall Reed. Photo by Paul Kenny.

Table 2: A comparison of species diversity at Biscayne National Park, Pescatello Preserve, and Garden Key, Florida. Data from Stalter et al. (2020e in press).

\begin{tabular}{|c|c|c|c|c|}
\hline Site & Native Species & Non-native species & Total species & \% Non-native species \\
\hline Biscayne N.P. & 298 & 82 & 380 & $21.60 \%$ \\
\hline Pescatello Preserve & 121 & 5 & 126 & $4 \%$ \\
\hline Garden Key & 84 & 60 & 144 & $41.60 \%$ \\
\hline
\end{tabular}

Garden Key, Dry Tortugas National Park, comprising less than a hectare, is the smallest Florida site studied by Stalter [14]. It is the site of Fort Jefferson where Dr, Samuel Mudd, was interned. He is the physician who tended to Lincoln assassin John W. Booth's injured leg and was thought to be part of the assassin conspiracy. Today Garden Key is visited by hundreds of people each day, a potential source of invasive taxa. Garden Key has the highest percent of invasive taxa, $41.6 \%$, of the three Florida sites presented in this paper.

\section{Methods}

\section{Collections}

Collection trips were made to the various sites by Stalter accompanied by some of the co- authors. Objectives for each trip included the collection of voucher specimens and to accumulate information on abundance and apparent habitat preference for each species. Specimens were sent to various experts for identification; their names are included in the acknowledgment section of the cited papers. Annotated checklists of the floras were included in all publications. Nomenclature followed that found in the appropriate state or regional vascular plant manuals.

\section{Results and Discussion}

There are numerous examples of the introduction of invasive plants and animals deliberately or accidentally introduced to new countries all over the world. While it is not the purpose of this paper to discuss these in detail a few of the most common examples follow: rabbits to Australia (deliberate) Mongoose to Caribbean islands (deliberate-rid islands of snakes) zebra mussel to the USA (accidental in ship ballast), starling to the USA (deliberate), Callery Pear (deliberate-attractive early flowering tree-planted along streets in eastern USA), Kudzu to the USA (deliberate- planted to stem erosion in the south), Multiflora Rose (deliberate-used extensively in USA for hedge plantings in the 1950's), Norway Maple (deliberate-street plantings), Oriental bitter 
sweet (deliberate U.S.A. attractive fruit), Australian Pine (deliberateplanted extensively in Florida), Brazilian Pepper (deliberate-attractive fruit-brought to Florida), Water Hyacinth (deliberate-attractive flowers- common in southern and eastern U.S.A. escaped when hurricane flooded ponds and dispersed plant). Many of the above plants have few or no insect pests that enables them to out-compete native plants. In addition, some produce allelopathic compounds that impact native vegetation. While most of the above were introduced deliberately, the seeds of many invasive plants have been accidently brought to this country on clothing, in vegetable seed packets, with animal imports, in soil of potted plants, ship ballast, imported cargo and more.

The number and percent of vascular plant species for New York, New Jersey, South Carolina and Florida follow. New York has 1993 native and 1490 (43\%) non-native taxa [15]. New Jersey's flora consists of 2,188 native and $1288(37 \%)$ non-native; these values are approximate. South Carolina has approximately 3,000 vascular plant species; no data is presented for invasive and native taxa. Florida boasts the highest number of taxa, 4,838 with 3,307 native plans and 1,531 (31.6\%) nonnative [16].

The impact of the number of non-native vascular plant species in a flora can be deceiving. Only 18 percent of the taxa in Hutchison Memorial Forest were non-native yet these invasive taxa have a profound effect on the vegetation. Microstegium vimineum is the dominant herbaceous plant forming almost pure stands in places. It's allelopathic properties also impact native taxa. Invasive Acer platanoides produces dense shade during the growing season. No vascular plant species were observed in areas where mature trees were established. Fortunately, trees can be eradicated whereas Microstegium and Alliaria should be weeded by hand. Unfortunately, these weeded areas will be quickly seeded in by surrounding Microstegium and Alliaria. Moreover, hand weeding these taxa is time consuming and on a large scale is worthless. Herbicides cannot be used to control these invasive taxa in a forest because of the destruction of neighboring native taxa. Phragmites (and rising sea level) may be the biggest threat to native vegetation at the abandoned rice fields at Georgetown, South Carolina. Phragmites has been sprayed with Round Up at Back Bay National Wildlife Refuge, Virginia. Continued spraying might select for herbicide resistant strains of Phragmites exacerbating control of this invasive taxon here in the future [14]. Further, weeding herbaceous vegetation may be effective on a small scale but impossible on a scale as large at Hutchison Memorial Forest or Alley Pond Park, New York.

The number of invasive taxa is highest at sites where human visitation is high, especially in the vicinity of New York City (Table 1). Lamont and Stalter [1] found that human visitation also contributed to the number and percent of invasive taxa at Orient Beach State Park, New York. Invasive taxa contributed 47 percent in the heavily visited eastern portion of the park whereas only 19 percent of the flora was invasive in the seldom visited "off limits" western section.

Invasive taxa can have a significant impact on the flora at rarely visited sites such as Rutgers University's ecological research forest, Mettler's Woods, also known as Hutchison Memorial Forest, New Jersey. Here Microstegium vimineum is the most abundant and dominant vascular plant species on the forest floor where it forms pure stands in places. Its growth and allelopathic properties may play a significant role in the reduction of the herbaceous flora. The abandoned rice fields at the Baruch Institute, Georgetown, South Carolina like Hutchison Memorial Forest have few species of invasive taxa. However, one invasive, Phragmites australis has a profound impact on native taxa on the vegetation at the abandoned rice fields. This aggressive grass may grow 3-4 meters tall and excludes native taxa where it has become established (Figure 2). Phragmites may be one of the primary reasons for the decline in the number of taxa at Alderly. The effect of $\mathrm{M}$. vimineum and $\mathrm{P}$. australis on native vascular plant species at forest sites (Microstegium) and marshes (Phragmites) rarely visited by humans may portend a serious threat that these taxa pose to our native flora in the eastern United States in the future.

\section{Acknowledgment}

The author thanks Jingjing Tong for formatting the tables and figures and Dwight Kincaid for reviewing the paper.

\section{References}

1. Lamont EE, R Stalter (1991) The vascular flora of Orient Beach State Park, Long Island, New York. Bulletin of the Torrey Botanical Club 118(4): 459-468.

2. Stalter R, N Tang (2002) The vascular flora of Statue of Liberty National Monument, New York Harbor. Bartonia 61: 123-130.

3. Stalter R, S Scotto (1999) The vascular flora of Ellis Island, New York City, New York. J Torrey Bot Soc 126(4): 367-375.

4. Stalter R, A Munir (2002) The vascular flora of Hoffman and Swinburne Islands New York Harbor, New York. J Torrey Bot Soc 129(1): 77-82.

5. Stalter R, J Rachlin (2018) The vascular plant species of sidewalk plots in Brooklyn and Queens: New York City's overlooked “island” flora. J Torrey Bot Soc 145: 263-270.

6. Stalter R (2004) The flora on the High Line, New York City, New York, J Torrey Bot Soc 131(4): 387-393.

7. Stalter R, J Rachlin (2020a) Eighty-three years of vascular plant change at Alley Pond Park, County, New York, J Torrey Bot Soc (2020 in press).

8. Stalter, RDG Howarth, E Franxhi (2020b) The vascular flora of Mettler 's Woods, Somerset County, New Jersey. Bios (2020 in press).

9. Bard GE (1952) Secondary succession on the piedmont of New Jersey. Ecological Monographs 22(3): 195-215.

10. Stalter R, J Rachlin, J Baden (2020c) A forty-seven-year comparison of the vascular flora at three abandoned rice fields, Georgetown, South Carolina. J Bot Res Inst Texas (2020 in press).

11. Stalter R (2016) The vascular flora of Garden Key and Fort Jefferson, Dry Tortugas National Park, Florida, USA, J Bot Res Inst Texas 10(2): 527534.

12. Stalter R, EE Lamont (2020d) Vascular flora of J. N. "Ding" Darling National Wildlife Refuge, Sanibel Island, Florida, USA, J Bot Res Inst Texas (2020 in press).

13. Stalter R, P Lynch, E Franxhi, C Dial, K Crevani, et al., (2020e) The vascular flora of the John J. Pescatello Torchwood Hammock Preserve, Little Torch Key, Florida. Bios (2020 in press).

14. Stalter R, EE Lamont (2016) The vascular flora of Back Bay National Wildlife Refuge and False Cape State Park, Virginia. Medical Research Archives. Copyright 2015 KEI Journals, pp. 34.

15. Werier D (2017) Catalogue of the vascular plants of New York State. Memoirs of the Torrey Botanical Society, 27.

16. Wunderlin R, PBF Hansen, HR Frank, FB Essig (2020) Atlas of the plants of Florida. Institute for Systematic Botany, University of South Florida, Tampa. 